P-ISSN: 2774-4574; E-ISSN: 2774-4582

TRILOGI, 2(3), September-Desember 2021 (284-294) @2021 Lembaga Penerbitan, Penelitian, dan Pengabdian kepada Masyarakat (LP3M) Universitas Nurul Jadid Paiton Probolinggo

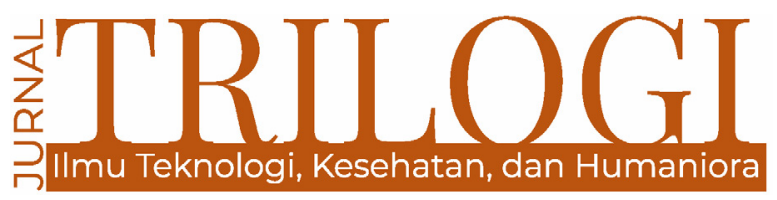

\title{
PARIWISATA HALAL DI INDONESIA: KAJIAN TERHADAP FATWA DEWAN SYARIAH NASIONAL MAJELIS ULAMA INDONESIA (DSN-MUI)
}

\section{Temmy Wijaya}

Universitas Nurul Jadid, Probolinggo, Indonesia temmy@gmail.com

\section{Siti Nurbayah}

Universitas Nurul Jadid, Probolinggo, Indonesia

\section{Fatimatus Zahro}

Universitas Nurul Jadid, Probolinggo, Indonesia

Fitria Ningsih

Universitas Nurul Jadid, Probolinggo, Indonesia

\begin{abstract}
Abstrak
Fenomena pengembangan pariwisata berbasis syariah kini telah menjadi keharusan bagi masyarakat Indonesia dan bahkan untuk masyarakat global. Oleh karena itu, dibutuhkan sedikitnya dua aturan yang mengaturnya. Kedua aturan tersebut berkaitan dengan syariah normatif dan peraturan yang mengatur implementasi secara hukum. Tujuan dari penelitian ini adalah untuk menggambarkan pariwisata halal di Indonesia dalam hal Fatwa Dewan Syariah Nasional Majelis Ulama Indonesia (DSN-MUI) dan Peraturan Pemerintah. Penelitian ini adalah tinjauan konseptual yang menggunakan metode penelitian literatur yang bersumber dari jurnal otoritatif, buku dan dokumen dan masih relevan dengan studi pariwisata halal. Hasil penelitian menunjukkan bahwa sejumlah besar permintaan publik untuk kunjungan pariwisata halal di Indonesia mengakibatkan perlunya regulasi normatif dan positif yang mengatur. Akhirnya, MUI mengeluarkan dan menetapkan nomor fatwa: 108 / DSN-MUI / IX / 2016 mengenai implementasi pariwisata berdasarkan prinsip syariah dan Nomor Peraturan Daerah Nusa Tenggara Barat. 2 tahun 2016 tentang pariwisata halal. Secara keseluruhan, indikator pariwisata halal sesuai dengan Nomor Fatwa DSN-MUI: 108 / DSN-MUI / X / 2016 dan Nomor Peraturan Daerah Nusa Tenggara Barat. 22016 Kontennya hampir sama dan saling terkait satu sama lain. Satu-satunya perbedaan adalah dalam penggunaan istilah "pariwisata syariah" dalam fatwa DSN-MUI sementara konten dalam peraturan regional (PERDA) menggunakan istilah "pariwisata halal".
\end{abstract}

Kata kunci: Fatwa DSN-MUI; Peraturan Regional; Pariwisata halal; Indonesia 


\begin{abstract}
The phenomenon of sharia-based tourism development has now become a necessity for the people of Indonesia and even for the global community. Therefore, we need rules and regulations that govern them, both rules relating to normative sharia and regulations governing legal implementation. The purpose of this study is to describe halal tourism in Indonesia in terms of the Fatwa of the National Sharia Council of the Indonesian Ulema Council (DSN-MUI) and Government Regulations. This research is a conceptual review that uses literature research methods sourced from authoritative journals, books and documents and is still relevant to the study of halal tourism. The results of the study indicate that a large number of public requests for halal tourism visits in Indonesia result in the need for normative and positive regulations that regulate. Finally, the MUI issued and determined the fatwa number: 108 / DSN-MUI / IX / 2016 regarding the implementation of tourism based on sharia principles and the West Nusa Tenggara Regional Regulation Number. 2 of 2016 concerning halal tourism. Overall, the halal tourism indicators are in accordance with the DSN-MUI Fatwa Number: 108 / DSN-MUI / X / 2016 and the West Nusa Tenggara Regional Regulation Number. 22016 The content is almost the same and interrelated with each other. The only difference is in the use of the term "sharia tourism" in the DSN-MUI fatwa while the content in regional regulations (PERDA) uses the term "halal tourism".
\end{abstract}

Keywords: DSN-MUI FATWA; Regional Regulations; Halal tourism; Indonesia

\section{Pendahuluan}

Proyeksi populasi baru oleh penelitian tentang agama \& forum kehidupan publik memperkirakan bahwa populasi Muslim dunia akan meningkat sekitar 35\% dalam 20 tahun ke depan, naik dari 1,6 miliar pada 2010 menjadi 2,2 miliar pada tahun 2030 (RRC-FLP, 2011; CCD , 2016). Sementara Muslim di Asia telah mencapai lebih dari dua pertiga dari populasi Muslim dunia yang tinggal di benua ini. Populasi Asia meningkat dari 1,4 miliar pada tahun 1950 hingga 4,7 miliar pada tahun 2020, persentase umat Islam di Asia meningkat dari 23\% pada tahun 1950 hingga $31 \%$ pada tahun 2020, yang berjumlah lebih dari satu persen per dekade (Ketani, 2010). Bahkan data terbaru menunjukkan bahwa umat Islam mengalami peningkatan pesat dalam populasi dunia, dan Indonesia mengalami tingkat yang lebih cepat daripada populasi Muslim di dunia antara tahun 1950 dan 2050 (Kettani, 2014). Saat ini, Indonesia adalah negara mayoritas Muslim terbesar di dunia dan Indonesia memiliki populasi Muslim terbesar dibandingkan dengan negara lain.

Berdasarkan data di atas, kondisi pasar global ketika didasarkan pada kebutuhan dan preferensi sekitar 1,6 miliar Muslim di seluruh dunia telah muncul sebagai arena komersial yang kuat. Ini menciptakan peluang bagi perusahaan, terutama di pasar berkembang untuk memanfaatkan pasar produk halal (González, 2015). Oleh karena itu, industri halal telah menarik banyak negara seperti Thailand, Singapura dan Filipina yang mengetahui perkembangan produk halal. Negaranegara lain seperti Amerika Serikat dan Australia juga berebut untuk mengambil kesempatan ini untuk menjadi produsen produk halal (Tawil et al., 2015). Pasar besar ini untuk pariwisata halal termasuk Bahrain, Yordania, Kuwait, Oman, Qatar, Arab Saudi, Uni Emirat Arab, Malaysia, Indonesia, Brunei dan pelancong Muslim dari Asia Selatan, Eropa, Amerika Serikat dan Inggris (Mohsin et al. , 2016).

Selama beberapa dekade terakhir, konsep Halal hanya menjadi perhatian bagi umat Islam, tetapi sekarang konsep Halal telah menjadi perhatian global di semua bisnis dan sektor industri (Elias et al., 2016). Perhatian publik terhadap produk halal ini menunjukkan bahwa ada kesadaran yang lebih besar di antara umat Islam tentang perlunya produk halal. Contoh yang baik untuk meningkatkan kesadaran konsumen adalah penjualan tahunan yang cepat dari makanan halal di seluruh Rusia dan meningkatnya permintaan untuk produk halal antara $30 \%$ dan $40 \%$ setiap tahun. Oleh karena itu, tidak ada keraguan jika saat ini semua pihak melihat halal sebagai sarana potensial untuk merangsang perekonomian melalui ekspor nilai tambah, perdagangan dan pariwisata. Kesadaran tentang konsep halal meningkat, dan perusahaan merespons dengan cepat terhadap kebutuhan konsumen ini, keduanya untuk produk atau layanan (Baharuddin et al., 2015).

Pengeluaran Muslim pada sektor-sektor ini telah meningkat di masa lalu karena beberapa pendorong utama pertumbuhan demografis, 
pertumbuhan ekonomi Islam, gaya hidup dan praktik bisnis dan fokusnya pada orientasi halal. Data dari keadaan ekonomi Islam global 20172018 menyatakan bahwa tren bisnis halal saat ini terus menunjukkan kemajuan, termasuk bisnis di sektor pangan halal (makanan halal), perjalanan halal (perjalanan halal), media halal dan rekreasi (media halal dan Rekreasi), Farmasi Halal dan Kosmetik (Halal Pharmaceuticals and Cosmetics) (Dinarstandard, 2018). Sekarang ketika seseorang berbicara tentang halal, itu tidak hanya merujuk pada makanan, tetapi juga semua hal dalam kehidupan sehari-hari. Halal mencakup semua aspek kehidupan manusia tanpa kecuali. Seorang Muslim berkewajiban untuk memastikan status hukum makanan apa pun sebelum memakannya (Tawil et al., 2015). Demikian juga, jika dia ingin bepergian, pariwisata halal adalah tur yang diizinkan oleh syariah untuk dikunjungi sementara pariwisata terlarang melanggar hukum.

Sektor pariwisata halal kini telah menjadi tren dan keharusan bagi negara-negara Muslim dan non-Muslim. Pariwisata halal adalah segmen pasar yang berkembang pesat tidak hanya di negaranegara Muslim tetapi secara global. Dengan fenomena yang tumbuh ini, dikombinasikan dengan meningkatnya jumlah wisatawan Muslim di seluruh dunia, beberapa negara non-Muslim juga telah memulai berbagai strategi untuk mendapat manfaat dari pariwisata halal. Di Jepang, misalnya, sudah mulai terlihat menarik bagi para wisatawan dari negara-negara Muslim terutama dari negara-negara Asia Tenggara untuk mengunjungi Jepang. Jepang telah menyediakan kamar sholat di bandara-bandara besar, dan beberapa restoran sekarang menyajikan makanan halal. Beberapa rantai restoran di Inggris, seperti KFC dan kereta bawah tanah juga menawarkan makanan halal kepada pelanggan Muslim mereka. Sementara itu, Otoritas Pariwisata Thailand telah meluncurkan aplikasi pariwisata Muslim yang disebut "Thailand Muslim Friendly". Ini dapat diunduh melalui Apple Store dan Google Play untuk membantu wisatawan Muslim menemukan restoran dan hotel halal, serta ruang sholat di negara-negara yang mereka kunjungi (Vulcan Post, 2019). Turki memprioritaskan strategi pariwisata sampai 2023, untuk mengembangkan pariwisata kesehatan dan termal, pariwisata musim dingin, pariwisata golf, pariwisata laut, ekowisata, pariwisata dataran tinggi dan pariwisata alternatif, yaitu pariwisata halal. Mengingat budaya dan aspek agama Turki saat ini, pariwisata halal adalah jenis pariwisata alternatif sebagai diversifikasi kegiatan pariwisata alternatif disertai dengan layanan berkualitas yang baik (Pamukçu dan Arpaci, 2016). Pada akhir 2013 Dubai telah memberikan titik fokus pada industri halal untuk semua proyek ekonomi Islam mulai dari keuangan Islam dan produk halal hingga pariwisata yang ramah keluarga, ekonomi digital, desain dan informasi Islam, dan sertifikasi (ITC, 2015).

Pariwisata halal telah menjadi tren baru di dunia global, yang termotivasi oleh meningkatnya jumlah pengunjung Muslim, yang terus meningkat setiap tahun (COMCEC, 2016). Indonesia sebagai negara dengan populasi Muslim terbesar di dunia juga menyetujui pentingnya pertumbuhan ekonomi baru melalui sektor pariwisata halal (Andriani, 2015). Pengeluaran pariwisata Muslim Indonesia mencapai \$9,7 miliar per tahun. Permintaan eksternal untuk sektor pariwisata Indonesia juga meningkat (Breuer et al., 2018). Pada tahap internasional, Indonesia menempati peringkat keempat dalam "10 perjalanan halal teratas" yang memperhatikan sektor pariwisata halal dalam pembangunan ekonominya. Indonesia menyadari potensinya sebagai tujuan utama bagi wisatawan Muslim, didukung oleh upaya substansial untuk mengembangkan pariwisata halal, tercermin dalam skor ekosistem yang tinggi, serta peningkatan substansial dalam diskusi media tentang pariwisata halal. Karena perilaku mencari informasi melalui media di antara keluarga Muslim juga memengaruhi keputusan perjalanan (Yusoff \& Adzharuddin, 2017).

Fenomena sosial pariwisata halal kini telah menjadi perkembangan baru di industri pariwisata baik di dalam negeri maupun di luar negeri. Namun, masih ada masalah dalam praktiknya, yaitu kurangnya standar perjalanan halal universal dapat menyebabkan kebingungan yang berkelanjutan di kalangan konsumen (terutama wisatawan Muslim) dan industri. Kurangnya aturan dan peraturan yang jelas dapat mengarah ke Mafsadat dan Madharat dalam Manajemen (Negara Bagian Ekonomi Islam Global 2017/2018). Keragaman dan fragmentasi industri pariwisata adalah salah satu masalah utama dalam mengukur dampak ekonomi dari pariwisata itu sendiri (Theobald 2005). Ada beberapa ambiguitas sehubungan dengan interpretasi konsep pariwisata halal, yang memengaruhi pendekatan implementasinya (Muhamad et al., 2017). Misalnya, temuan empiris Islam dan Kärkkäinen (2013) menunjukkan bahwa kebutuhan dan tuntutan wisatawan Muslim secara keseluruhan harus dianggap sebagai kebutuhan 
halal yang berakar pada gaya hidup Muslim. Temuan ini juga menunjukkan bahwa ketersediaan makanan halal, ruang doa di fasilitas akomodasi, lingkungan khusus untuk wanita seperti spa dan kolam renang terpisah adalah beberapa kebutuhan halal yang mendesak yang belum ditemukan dan dipenuhi.

Pariwisata juga dianggap oleh beberapa orang untuk menjadi berbahaya bagi lingkungan karena membutuhkan pembangunan bangunan tambahan dan kegiatan lain yang akan menghasilkan polusi. Beberapa sarjana Islam khawatir tentang keberadaan pariwisata karena mereka berpikir bahwa itu akan mengarah pada pertukaran atau pencampuran berbagai tradisi budaya, nilainilai, kepercayaan dan sikap. Oleh karena itu, mereka menentang hal-hal seperti itu agar tidak mengikis nilai-nilai dan budaya Islam (Sanad, et al., 2010: 21). Intinya, industri pariwisata selalu dipengaruhi oleh agama, terutama Islam, karena aturan dan peraturan khususnya (Namin, 2012). Agama telah lama dikenal sebagai faktor yang berpengaruh dalam pariwisata, terutama yang terkait dengan pariwisata halal (Idul Fitri \& ElGohary, 2014). Pengaruh agama pada pergerakan wisatawan adalah fakta yang tak terbantahkan (Mansouri, 2014).

Berdasarkan uraian di atas, industri pariwisata halal (industri pariwisata halal) muncul sebagai sub-sektor baru di industri pariwisata global (Suharko, et al., 2018). Penyediaan barang dan jasa halal harus disertai dengan sertifikasi halal yang dikeluarkan oleh Pemerintah melalui Badan Jaminan Produk Halal (BPJPH) Kementerian Agama Republik Indonesia di mana fatwa dikeluarkan oleh Dewan Ulama Indonesia (MUI). Fatwa dapat memberikan solusi untuk fenomena sosial terbaru yang terjadi di masyarakat (Fariana, 2017). Keberadaan MUI dianggap sangat penting, yaitu pada posisi pemberian fatwa. Dalam praktik industri halal, Fatwa MUI menjadi referensi hukum dalam meneliti dan mensertifikasi halal produkproduknya.

Jika dilihat dari perspektif hukum positif, fatwa memang tidak mengikat tetapi mengikat adalah norma, yang sering digunakan sebagai norma hukum yang kemudian ditentukan oleh negara (Mulyati, 2019). Sebagaimana dinyatakan oleh Johar (2019), meskipun Fatwa MUI tidak berada dalam posisi yang sama dengan hukum positif yang telah mengikat daya untuk semua warga negara, tetapi Fatwa MUI dapat atau dapat memiliki kekuatan yang mengikat setelah ditransformasikan menjadi peraturan hukum,
The Fatwa juga dapat diubah menjadi peraturan pemerintah (PP) atau peraturan regional (PERDA) di tingkat provinsi atau kabupaten atau kota (Johar, 2019). Seperti munculnya fatwa Badan Syariah Nasional - Majlis Ulama Indonesia Nomor: 108 / DSN-MUI / X / 2016 tentang Pedoman Pengorganisasian Pariwisata Berdasarkan Prinsip Syariah dan Peraturan Daerah Nusa Tenggara Barat Nomor 2 Tahun 2016 Mengenai Pariwisata Halal. Karena perkembangan pariwisata halal di NTB terus mengalami peningkatan yang signifikan, terutama setelah provinsi NTB didirikan sebagai tujuan pariwisata halal di Indonesia pada tahun 5015. Ini mendorong pemerintah daerah NTB untuk mengatur praktik pariwisata halal melalui Nomor Perda. 2 tahun tentang pariwisata halal yang dikeluarkan pada 2016, dan NTB menjadi wilayah atau provinsi pertama di Indonesia untuk memiliki peraturan pariwisata halal. Selain dimaksudkan sebagai pedoman bagi manajer pariwisata dalam menyediakan layanan pariwisata halal kepada wisatawan, tetapi juga dimaksudkan untuk memberikan layanan keamanan dan kenyamanan kepada wisatawan sehingga mereka dapat menikmati kunjungan wisata yang aman dan halal (Fahham, 2017: 73). Peringkat Pemerintah Aceh berusaha untuk mewujudkan pariwisata halal di daerah mereka, tetapi Aceh belum mengeluarkan peral (Qanun) pariwisata halal (Saleh \& Anisah, 2019). Tidak seperti NTB, yang sudah memiliki peraturan pariwisata halal. Oleh karena itu, selain peraturan daerah, perubahan sosial sebagai akibat dari dinamika budaya seperti lingkungan pariwisata halal saat ini membutuhkan peran ulama untuk menerjemahkan transformasi sosial budaya ke dalam fatwa.

Berdasarkan latar belakang yang telah dijelaskan di atas, studi tentang pariwisata halal di Indonesia, dalam perspektif DSN-MUI Fatwa dan Perda sangat penting untuk dilakukan dan memiliki nilai strategis dalam mengeksplorasi dan menemukan standardisasi indikator pariwisata alternatif yang Sesuai dengan nilai-nilai AI-Qur'an dan mendukung pengembangan pariwisata berkelanjutan melalui pariwisata halal di Indonesia.

\section{Metode}

Penelitian ini adalah penelitian konseptual yang menggunakan metode penelitian literatur yang bersumber dari jurnal otoritatif, buku dan dokumen dan masih relevan dengan studi pariwisata halal. 


\section{Hasil dan Pembahasan}

Saat ini pariwisata telah tumbuh secara signifikan dalam kepentingan ekonomi dan sosial. Sektor ekonomi yang paling cepat berkembang di sebagian besar negara industri dalam beberapa tahun terakhir ada di sektor jasa. Salah satu segmen terbesar dari industri jasa, meskipun sebagian besar tidak diakui sebagai entitas di beberapa negara ini, adalah perjalanan dan pariwisata (Theobald, 2005). Oleh karena itu, pariwisata secara langsung atau tidak langsung berada di garis depan dalam penciptaan komunitas global (Chang, 2007).

Pariwisata Menurut Undang-Undang Republik Indonesia Nomor 10 Tahun 2009 tentang Pariwisata adalah berbagai kegiatan pariwisata dan didukung oleh berbagai fasilitas dan layanan yang disediakan oleh masyarakat, pebisnis, pemerintah, dan pemerintah daerah. Letmorish dan Jenkins (1997) menggambarkan pariwisata sebagai kegiatan yang melintasi sektor konvensional dalam perekonomian. Ini membutuhkan input yang bersifat ekonomi, sosial, budaya dan lingkungan. Dalam hal ini sering digambarkan sebagai keragaman (Lickorish \& Jenkins, 1997. Seperti juga dijelaskan oleh Goeldner dan Ritchie (2012) yang mengatakan bahwa pariwisata adalah kombinasi dari berbagai kegiatan, layanan, dan industri yang memberikan pengalaman perjalanan: transportasi, akomodasi, akomodasi, akomodasi, Tempat Makan dan Minuman, Toko, Hiburan, Fasilitas Aktivitas, dan Layanan Perhotelan Lainnya tersedia untuk individu atau kelompok yang bepergian jauh dari rumah.

Seiring dengan pertumbuhan kegiatan pariwisata, industri pariwisata telah berkembang pesat selama beberapa dekade terakhir, yang mencerminkan perkembangan perkembangan pengakuan pariwisata sebagai salah satu kekuatan ekonomi, sosial dan lingkungan yang paling signifikan di rumah dan di luar negeri (Hudson, 2008). Banyak negara saat ini bersaing untuk membuat inovasi dan mendiversifikasi bisnis mereka dari pariwisata, pariwisata halal, misalnya, untuk memenuhi permintaan dan kebutuhan pariwisata berdasarkan gaya hidup wisatawan Muslim dari berbagai negara, sehingga mereka menyediakan produk dan layanan pariwisata yang sesuai dengan dengan ajaran dan nilai-nilai Islam (Mohsin et al., 2016).

Mengintegrasikan dan menggabungkan istilah "halal" dalam membentuk "pariwisata halal" tidak dapat dipisahkan dari istilah "halal" itu sendiri. Kata ḥalāl berasal dari arab etimologis yang berarti diizinkan, diizinkan, legal dan legal. Istilah ḥAāl berarti diizinkan sesuai dengan ajaran Islam (Syariah). Halal juga merupakan salah satu dari lima tindakan al-Ahkām al-Khamsah yang mengkategorikan moralitas tindakan manusia dalam Islam, lawan atau kebalikan dari halal adalah haram (terlarang) (al-Qaradawi, 2013). HAlāl dalam Alquran biasanya digunakan sehubungan dengan apa yang dimungkinkan oleh kemauan dan perintah Allah, dan, sejauh itu, membawa kemurnian tingkat yang lebih tinggi daripada label hukum Jā'iz dan Mubāh (Kamali, 2011). Menurut Islam setiap Muslim berkewajiban hanya mengkonsumsi apa yang halal dan menghindari apa yang dilarang oleh Allah SWT. Karena memakan halal, suci dan baik (Thayyib) adalah komando agama dan hukum adalah wajib (Amin, 2011).

Berdasarkan uraian ini, pariwisata Islam didefinisikan sebagai pariwisata yang sesuai dengan Islam, yang melibatkan orang-orang Muslim yang tertarik untuk mempertahankan kebiasaan agama pribadi mereka saat bepergian. Definisi ini tidak terbatas pada perjalanan untuk keperluan agama dan tidak secara eksklusif melakukan perjalanan ke atau di dalam negaranegara Muslim (Carboni et al., 2014). Definisi pariwisata halal mengacu pada objek wisata atau tujuan dan tindakan yang diizinkan sesuai dengan ajaran Islam untuk digunakan atau terlibat oleh umat Islam di industri pariwisata (Battour \& Ismail, 2016). Pariwisata halal adalah bentuk pariwisata agama yang mewakili kepatuhan dan kepatuhan terhadap ajaran Islam, menawarkan tujuan yang menyediakan produk dan layanan halal yang cocok untuk wisatawan Muslim. Pariwisata halal memberikan pilihan alternatif bagi wisatawan Muslim karena meyakinkan mereka bahwa masalah dan hal-hal yang berkaitan dengan kepatuhan terhadap hukum Syariah harus dipertahankan. Ini, dalam arti memberi mereka ketenangan pikiran ketika mereka bepergian, sebagai pengganti pariwisata konvensional (Bon \& Hussain, 2010), di mana wisatawan Muslim harus secara aktif mencari produk dan layanan berbasis halal atau menghindari hal-hal tertentu untuk memenuhi persyaratan halal. (Isa et al., 2018).

Secara teoritis, literatur tentang pariwisata jarang menyentuh atribut agama, terutama ketika berbicara tentang atribut Islam (Battor et al., 2011). Karena orang lebih akrab dengan istilah pariwisata konvensional daripada pariwisata halal. 
Ada dua pendekatan untuk memahami konsep pariwisata agama berdasarkan perspektif dan tujuan pariwisata atau perjalanan.

Bepergian sangat direkomendasikan oleh Alquran. Allah meminta manusia untuk melakukan perjalanan melalui bumi untuk mengambil pelajaran dari ciptaannya yang ia tawarkan kepada manusia dalam belas kasihannya (Alquran Surat al-'ankabut (29): 20) yang berarti: Katakan: "WAKTU) Bumi, lalu Pertimbangkan bagaimana Allah menciptakan (manusia) dari awalnya, maka Allah membuatnya sekali lagi. " Tentunya Allah memiliki kekuatan atas semua hal. Ayat ini menunjukkan fakta yang mapan bahwa agama memiliki pengaruh pada kegiatan sehari-hari umat Islam, baik di rumah atau bepergian atau bepergian, dan dengan demikian akan membentuk pilihan terhadap tujuan yang baik dan bijaksana. Islam mengakui hak orang untuk pindah dari satu tempat ke tempat lain dan mendorong perjalanan ke tujuan yang berguna termasuk haji dan umrah, ziarah, kesehatan dan kedokteran, pendidikan, bisnis, perdagangan, hiburan, dan kesenangan. Namun, kata-kata seperti "kesenangan" dan "hiburan" harus ditafsirkan dengan hati-hati karena umat Islam diizinkan untuk mencari kesenangan dan hiburan hanya dengan cara yang sah atau tidak melebihi peraturan dan kewajiban syariah Islam. Oleh karena itu, dalam konteks ini, kebijakan pariwisata, tujuan pengembangan dan manajemen dan operasi industri pariwisata sangat dipengaruhi oleh prinsip-prinsip Islam (Sanad et al., 2010).

Pariwisata Islam sebagai konsep yang telah digunakan dengan berbagai syarat dan konotasi dalam teori dan praktik pariwisata. Pariwisata halal (pariwisata halal), perjalanan halal (perjalanan halal), pariwisata Islam dan pariwisata yang ramah Muslim (pariwisata ramah Muslim) adalah istilah yang paling umum, yang digunakan sebagai alternatif. Selain itu, ada sejumlah istilah terkait seperti "keramahan halal", "hotel yang sesuai dengan syariah", "perjalanan yang ramah halal" dan sebagai tujuan yang ramah terhadap Muslim yang menyinggung layanan di sektor ini (Sesric, 2018: 3) .

\section{Pentingnya Fatwa DSN-MUI dan Peraturan Daerah Pariwisata Halal}

Saat ini penerapan konsep halal dalam kegiatan pariwisata telah menjadi kebutuhan bagi orang-orang di Indonesia. Ini dibuktikan dengan banyak permintaan untuk pariwisata halal, ini dapat dilihat dari jumlah pengunjung yang bepergian ke tujuan yang sudah memiliki merek halal. Selain NTB dan Aceh, Sumatera Utara adalah salah satu provinsi yang kini telah mengembangkan konsep pariwisata halal. Beberapa tempat wisata sekarang mulai dicoba dalam penerapan konsep pariwisata halal (Pradesyah \& Khairunnisa, 2018). Pariwisata halal adalah kegiatan pariwisata yang menekankan bahan dan metode penanganan halal berdasarkan syariah (Cholis et al., 2019). Prinsip Syariah yang diterapkan dalam pariwisata berasal dari dua sumber utama yaitu Quran dan As-Sunnah serta dua sumber sekunder yaitu ijtihad melalui Ulama Fatwa yang dipromosikan oleh Dewan Ulama (MUI) Indonesia dan Perda yang dikeluarkan oleh masing-masing pemerintah daerah (Setiyanto, 2018).

Dalam hal ini Dewan Ulama Indonesia (MUI) telah mengeluarkan fatwa pada implementasi pariwisata berdasarkan prinsip syariah Nomor: 108 / DSN-MUI / IX / 2016. Fatwa berisi implementasi pariwisata yang sesuai dengan syariah termasuk, di antara Hal-hal lain, wisatawan, agen perjalanan, pariwisata pengusaha, hotel, pemandu wisata dan terapis. Pemerintah Daerah NTB juga memiliki Nomor Peraturan Daerah Nusa Tenggara Barat. 2 tahun 2016 tentang pariwisata halal (Fateh, 2018). Fatwa dan peraturan daerah ini juga menjawab fenomena pariwisata halal yang menjadi tren di Indonesia dan internasional. Sehingga fatwa dan peraturan daerah ini menjadi kebutuhan bagi semua pemangku kepentingan pariwisata halal dalam mengatur kegiatan pariwisata sesuai dengan prinsip syariah.

Majlis Ulama Indonesia (MUI) adalah lembaga yang memiliki tugas memberikan fatwa tentang masalah yang menjadi kebutuhan publik yang strategis. Fatwa MUI yang dikeluarkan oleh Komisi Fatwa memiliki pengaruh yang sangat luas karena MUI menjadi lembaga yang mengakomodasi semua organisasi sosial, termasuk komunitas Nahdlatul Ulama (NU) dan mayoritas Muhammadiyah di Indonesia (Ma'mur, 2018). Fatwa memiliki peran penting bagi masyarakat di Indonesia, terutama Muslim. Mayoritas Muslim membutuhkan jawaban hukum selektif dan kontekstual untuk kegiatan pariwisata berdasarkan prinsip syariah.

Keberadaan Fatwa MUI dilihat dari aspek sosial, dianggap sangat penting (mendesak) di tengah-tengah realitas pluralitas masyarakat Islam Indonesia. Peran MUI Fatwa sangat diinginkan untuk menyatukan masyarakat yang beragam ini. Sejalan dengan fungsinya dan perannya 
sebagai intelektual, MUI membawa mandat besar untuk dapat mengakomodasi kemampuan atau kekuatan yang ada dalam dirinya sendiri untuk kepentingan masyarakat pada umumnya dan Muslim pada khususnya (Johar, 2019). Meskipun keberadaan MUI disebutkan dalam berbagai produk hukum seperti Undang-Undang Jaminan Produk Halal, MUI masih bersikeras bahwa mereka adalah organisasi non-pemerintah di luar pemerintah (Abdillah \& Novianto, 2019). Sebagai lembaga Islam dan organisasi non-pemerintah di Indonesia, MUI selalu independen (Habibaty, 2017). Selain menerbitkan dan menetapkan fatwa (Wahyudi \& Fajar, 2018), Dewan Ulama Indonesia (MUI) juga membimbing Muslim dan Pemerintah. MUI memiliki pengaruh dan otoritas hukum fatwa-nya, telah memberikan peran dan otoritas kelembagaan baru dalam banyak hal, seperti hal-hal sertifikasi halal, keuangan Islam, dan ziarah (Lindsey, 2012).

MUI memiliki misi Khidmatul Ummah sebagai aspek layanan; Himayatul Ummah, melindungi umat dari praktik kehidupan Ummah yang dilarang dalam Islam. Termasuk melindungi orang dari mengkonsumsi produk yang tidak jelas halal. Juga, sebagai Shodiqul Hukumah atau mitra pemerintah yang membantu membimbing atau mengarahkan pemerintah sehubungan dengan aspek-aspek sosial agama dalam kehidupan bangsa dan negara bagian (Amin, 2018). Dalam melaksanakan misinya Dewan Ulama Indonesia (MUI) membentuk Dewan Syariah Nasional (DSN) yang ditugaskan untuk mengawasi dan mengarahkan lembaga keuangan dan lembaga bisnis Islam untuk mendorong penerapan ajaranajaran Islam dalam kegiatan keuangan dan ekonomi. DSN dibentuk melalui Surat Keputusan Dewan Kepemimpinan MUI tentang pembentukan Nomor Dewan Syariah Nasional (DSN). KEP-754 / MUI / II / 99 (FATEH, 2018).

Secara umum, urgensi peraturan pariwisata halal tentang pariwisata halal adalah untuk melindungi umat Islam dan masyarakat Indonesia sehingga perilaku mereka dipertahankan dan sesuai dengan aturan hukum Islam saat bepergian atau melaksanakan kegiatan pariwisata. Ini sejalan dengan tujuan Dewan Ulama Indonesia dan peraturan daerah, yaitu untuk menciptakan masyarakat yang aman dan harmonis sesuai dengan prinsip-prinsip Syariah (Halal) dan dasar Negara Indonesia (Pancasila).

Tabel 1: Indikator Pariwisata Syariah (Pariwisata Halal) Menurut DSN-MUI

\begin{tabular}{|c|c|c|}
\hline Number & Variable & Indicators \\
\hline 1 & $\begin{array}{l}\text { Principles of Sharia Tourism } \\
\text { Organization }\end{array}$ & $\begin{array}{l}\text { Avoiding polytheism, disobedience, disobedience, tabdzir/israf, and disbelief; } \\
\text { Creating benefit and benefits both materially and spiritually. }\end{array}$ \\
\hline 2 & $\begin{array}{l}\text { The Stakeholders in Sharia } \\
\text { Tourism Organization }\end{array}$ & $\begin{array}{l}\text { 1) Tourists; } \\
\text { 2) Sharia Travel Bureau (BPWS); } \\
\text { 3) Tourism Entrepreneurs; } \\
\text { 4) Sharia hotels; } \\
\text { 5) Tour Guide; } \\
\text { 6) Therapist. } \\
\text { The contract between the parties that have the contract in the implementation } \\
\text { of sharia tourism is obliged to use a covenant in accordance with the DSN-MUI } \\
\text { fatwa and applicable laws and regulations. }\end{array}$ \\
\hline 3 & $\begin{array}{l}\text { Sharia Hotel (Lodging/ } \\
\text { Homestay) Criteria }\end{array}$ & $\begin{array}{l}\text { Sharia hotels may not provide access to pornography and immoral acts. } \\
\text { Sharia hotels may not provide entertainment facilities that lead to polytheism, } \\
\text { immorality, pornography and / or immoral acts. } \\
\text { Food and beverages provided by sharia hotels must have obtained halal } \\
\text { certificates from MUI. } \\
\text { Provide adequate facilities, equipment and facilities for the implementation of } \\
\text { worship, sanctification facilities. } \\
\text { Hotel management and employees / employees are required to wear clothes } \\
\text { that are in accordance with Sharia. } \\
\text { Sharia hotels are required to have guidelines and / or guidelines regarding } \\
\text { hotel service procedures to ensure the implementation of hotel services in } \\
\text { accordance with sharia principles. } \\
\text { Islamic hotels must use the services of Islamic Financial Institutions in } \\
\text { conducting services. }\end{array}$ \\
\hline
\end{tabular}




\begin{tabular}{|c|c|c|}
\hline 4 & $\begin{array}{l}\text { Provisions Regarding } \\
\text { Travelers }\end{array}$ & $\begin{array}{l}\text { Sticking to the principles of sharia by avoiding shirk, immorality, evil, and } \\
\text { damage (fasad); } \\
\text { Maintaining the obligations of worship during the tour; } \\
\text { Maintain noble character; } \\
\text { Avoid tourist destinations that are contrary to Islamic principles. }\end{array}$ \\
\hline 5 & $\begin{array}{l}\text { Sharia Travel Destinations } \\
\text { Provisions: }\end{array}$ & \\
\hline 5.1 & $\begin{array}{l}\text { Sharia Tourism Destinations } \\
\text { Must Be Aimed At Efforts To : }\end{array}$ & $\begin{array}{l}\text { Realizing public benefit; } \\
\text { Enlightenment, refreshment and appeasement; } \\
\text { Maintain trust, safety and comfort; } \\
\text { Achieve universal and inclusive goodness; } \\
\text { Maintaining cleanliness, nature conservation, sanitation, and the environment; } \\
\text { Respect for socio-cultural values and local wisdom that does not violate sharia } \\
\text { principles. }\end{array}$ \\
\hline 5.2 & $\begin{array}{l}\text { Sharia Travel Destinations } \\
\text { Must Have: }\end{array}$ & $\begin{array}{l}\text { Worship facilities that are appropriate to use, easily accessible and meet } \\
\text { shariah requirements; } \\
\text { Halal food and beverages that are guaranteed halal with MUI Halal Certificate. }\end{array}$ \\
\hline 5.3 & $\begin{array}{l}\text { Sharia Tourism Destinations } \\
\text { Must Avoid: }\end{array}$ & $\begin{array}{l}\text { Polytheism and Khurafat; } \\
\text { Immorality, adultery, pornography, porno-action, liquor, drugs and gambling; } \\
\text { Performing arts and culture as well as attractions that conflict with Islamic } \\
\text { principles. }\end{array}$ \\
\hline
\end{tabular}

\section{Indikator pariwisata syariah atau halal menurut DSN-MUI dan regulasi regional}

Kebutuhan dan tuntutan wisatawan Muslim untuk pariwisata halal secara keseluruhan harus ditangkap sebagai kebutuhan halal yang berakar pada gaya hidup Muslim (Islam \& Kärkkäinen, 2013). Karena inti dari wisata syariah (pariwisata halal) memahami arti syariah dan implementasinya dalam semua aspek kegiatan pariwisata mulai dari fasilitas penginapan, fasilitas transportasi, fasilitas, makanan dan minuman, sistem keuangan, hingga fasilitas dan penyedia layanan pariwisata diri mereka sendiri (Priyadi, 2016). Berikut ini adalah indikator pariwisata syariah (pariwisata halal) yang diekstraksi dari fatwa Dewan Badan Syariah Nasional Nasional Indonesia: 108 / DSN-MUI / X / 2016 tentang pedoman untuk mengatur pariwisata berdasarkan prinsip-prinsip syariah.

Secara garis besar, pada dasarnya indikator pariwisata halal sesuai dengan Nomor Fatwa DSNMUI: 108 / DSN-MUI / X / 2016 tentang Pedoman untuk mengatur pariwisata berdasarkan prinsip syariah tidak jauh berbeda atau kontennya hampir sama dengan Nusa Tenggara Barat Regional Peraturan Nomor 22016 tentang pariwisata halal. Misalnya dalam peraturan yang diatur, pengelolaan tujuan pariwisata halal harus membangun fasilitas publik untuk mendukung kenyamanan kegiatan pariwisata halal. Penyedia makanan dan minuman bersertifikat halal berkewajiban untuk menjamin halal makanan / minuman yang dilayani, mulai dari pasokan bahan baku hingga proses presentasi sebagaimana dibuktikan oleh "Sertifikat Halal" (Adinugraha, 2018). Setiap wirausahawan spa, sauna, dan pijat halal wajib menggunakan produk "Logo Halal Resmi". Setiap pariwisata pariwisata Bureau Manajer berkewajiban untuk mengatur paket perjalanan yang sesuai dengan kriteria pariwisata halal berdasarkan prosedur operasi standar (SOP) yang merujuk pada ketentuan DSN-MUI.

Dalam Fatwa DSN MUI menggunakan istilah "pariwisata syariah" sedangkan konten di Perda menggunakan istilah "pariwisata halal". Peraturan Regional juga menyatakan bahwa industri pariwisata halal adalah bisnis pariwisata yang menjual layanan pariwisata dan produk yang didasarkan pada prinsip syariah sebagaimana diatur oleh DSN-MUI. Pariwisata halal juga didefinisikan sebagai kegiatan kunjungan wisatawan dengan tujuan pariwisata dan industri yang menyiapkan produk pariwisata, layanan, dan fasilitas manajemen yang sesuai dengan syariah. Tujuan dari standar syariah adalah untuk mendapatkan sertifikasi dari DSN-MUI. Selain transparansi, akuntabilitas dan keadilan dalam mengimplementasikan pariwisata halal harus berbasis partisipatif. Oleh karena itu pemberdayaan masyarakat melalui pariwisata halal termasuk memperkuat kesadaran publik; dan meningkatkan kapasitas dan peran masyarakat dalam manajemen bisnis; dan meningkatkan pendapatan masyarakat. 


\section{Kesimpulan}

Indonesia sebagai negara multi-budaya dan multi-etnis, tentu saja ada masalah baru yang terus muncul di mana hukum tidak ditemukan baik dalam Al-Quran atau Hadits, seperti munculnya fenomena permintaan publik untuk pariwisata Indonesia. Dalam mengatasi dan menjawab masalah kehidupan sosial dan ekonomi tanpa batas ini, Islam telah memberikan legalitas kepada rakyatnya untuk melakukan Ijtihad melalui MUI dan pemerintah daerah dengan menerbitkan dan menetapkan fatwa dan peraturan. Yaitu fatwa pada implementasi pariwisata berdasarkan prinsip syariah Nomor: 108 / DSN-MUI / IX / 2016 dan Peraturan Daerah Nusa Tenggara Barat Nomor 2 tahun 2016 tentang pariwisata halal. Posisi Fatwa untuk Muslim menempati posisi yang sangat penting dan digunakan sebagai referensi, karena fatwa dibuat dan dikeluarkan oleh orang-orang yang memiliki wewenang di bidang agama. Ini sama pentingnya dengan posisi peraturan daerah yang dibuat untuk melakukan konstitusi tahun 1945 dan mungkin tidak bertentangan dengan peraturan yang ada di atasnya, sebagaimana diatur dalam Undang-Undang Nomor 12 tahun 2011 tentang Pembentukan Peraturan PerundangUndangan.

\section{Daftar Pustaka}

Abdillah, A., \& Novianto, R. (2019). The QuasiNon-Governmental Organization (QUANGO) in the Indonesian state administration system: The Indonesian Ulema Council. Jurnal Hukum \& Pembangunan, 49(1). https://doi.org/10.21143/jhp.vol49. no1.1913

Adinugraha, H. H. (2018). Halal tourism village: Concept and implementation in Indonesia. Human Falah, 5(1), 1-21. http://jurnal. uinsu.ac.id/index.php/humanfalah/article/ view/1336

Al-Qaradawi, Y. (2013) The lawful and the prohibited in Islam. Mesir: Shoruuk International.

Amin, M. (2018). Halal fatwa as manifestation of the mission of Himayatul Ummah MUI. International Annual Conference on Fatwa MUI Studies in Depok, Jawa Barat, held on July 26 2018. http://www. halalmui.org/mui14/index.php/main/ detil_page/138/24566.
Amin, M. (2011). Fatwas in the Islamic legal system. Jakarta, Indonesia: Elsas.

Andriani, D. K. K. (2015). Final report of the study on sharia tourism development. Jakarta: Deputi Bidang Pengembangan Kelembagaan Kepariwisataan.

Baharuddin, K., Kassim, N. A., Nordin, S. K., \& Buyong, S. Z. (2015). Understanding the halal concept and the importance of information on halal food business needed by potential Malaysian entrepreneurs. International Journal of Academic Research in Business and Social Sciences 5(2), 170-180. https://doi.org/10.6007/ijarbss/ v5-i2/1476

Battour, M., \& Ismail, M. N. (2016). Halal tourism: Concepts, practises, challenges and future. Tourism Management Perspectives, 19, 150-154. https://doi.org/10.1016/j. tmp.2015.12.008

Bon, M., \& Hussain, M. (2010). Halal. In N. Scott \& J. Jafari (Eds.), Tourism in the Muslim world: Bridging tourism theory and practice (vol. 2, pp. 4759). Bingley: Emerald Group Publishing Limited. https://doi.org/10.1108/S20421443(2010)0000002007

Breuer, L. E (2018) Realizing Indonesia's economic potential. Washington, DC: International Monetary Fund.

Carboni, M., Perelli, C., \& Sistu, G. (2014). Is Islamic tourism a viable option for Tunisian tourism? Insights from Djerba. Tourism Management Perspectives, 11, 1-9. https:// doi.org/10.1016/j.tmp.2014.02.002

Chang, P. R. (2007). Tourism management in the 21st century. New York: Nova Science Publishers, Inc.

Cholis, A. F., Hakim, L., \& Pangestuti, E. (2019). Sharia tourism development strategy in natural recreation sites of Batu City, East Java. International Journal of Applied Sciences in Tourism and Events, 3(1), 24-37. http://doi.org/10.31940/ijaste. v3i1.1337

Committee Cooperation for Development (CCD). (2016). Muslim friendly tourism: Developing and marketing MFT products and services in the OIC member countries. Turki: COMCEC Coordination Office.

DinarStandard. (2018). State of the global Islamic economy report 2017-2018. https://www. flandersinvestmentandtrade.com/export/ sites/trade/files/attachments/State $\% 20$ 
of $\% 20$ the $\% 20$ Global\%20Islamic $\% 20$ Economy\%202017-18.pdf

Eid, R., \& El-Gohary. H. (2014). Muslim tourist perceived value in the hospitality and tourism industry. Journal of Travel Research, 54(6), 774-787. https://doi. org/10.1177/0047287514532367.

Elias, E. M., Othman, S. N., Yaacob, N. A., \& Saifudin, A. M. (2016). A study of halal awareness and knowledge among entrepreneur undergraduates. International Journal of Supply Chain Management, 5(3), 147-152. https://ojs.excelingtech.co.uk/ index.php/IJSCM/article/view/1239.

Fahham, A. M. (2017). The challenge of developing halal tourism in Nusa Tenggara Barat. Jurnal Masalah-Masalah Sosial 8(1), 65-79. https://jurnal.dpr.go.id/index.php/aspirasi/ article/view/ 1258

Fariana, A. (2017). The importance of the mui fatwa in the development of the Islamic economic legal system in Indonesia. Al-Ihkam, 12(1), 87. https://doi.org/10.19105/alihkam. v12i1.1191

Fateh, M. (2018). Konstruksi filosofis fatwa DSN-MUI [The philosophical construction of DSI-MUI fatwa]. Jurnal Hukum Islam, 16(2), 155-171. https://doi.org/10.28918/ jhi.v16i2.1736

Goeldner, C. R., \& Ritchie, J. R. B. (2012). Tourism: principles, practices, philosophies (12th ed.). Hoboken, NJ: John Wiley \& Sons, Inc.

Habibaty, D. M. (2017). The role of the fatwa of the National Sharia Council of the Indonesian Ulema Council on Indonesian positive law. Jurnal Legislasi Indonesia, 14(4), 447-453. https://e-jurnal.peraturan.go.id/index.php/ jli/article/view/125

Hudson, S. (2008). Tourism and hospitality marketing: A global perspective. London, UK: Sage Publications Ltd.

International Trade Centre (ITC). (2015). From niche to mainstream halal goes global. Geneva: The International Trade Centre.

Isa, S. M., Chin, P. N., \& Mohammed, N. U. (2018). Muslim tourist perceived value: A study on Malaysia halal tourism. Journal of Islamic Marketing, 9(2), 19. https://doi. org/10.1108/JIMA-11-2016-0083

Islam, M. A., \& Karkkainen, L. (2013). Islamic tourism as a prosperous phenomenon in Lapland (MasterThesis, Rovaniemi University of Applied Sciences). https://www.theseus.
fi/bitstream/handle/10024/65659/Thesis_ Aminul_Laura.pdf

Johar, A. F. (2019). The legal strength of the fatwa of the Indonesian Ulema Council (MUI) from the perspective of the legislation in Indonesia. http://pa-negarakalsel.go.id/ images/images/PDF/Kekuatan_Hukum_ Fatwa_Majelis_Ulama_Indonesia.pdf.

Kamali, M. H. (2011). Tourism and the halal industry: A global shariah perspective. ICR Journal, 3(3), 456-473. https://icrjournal. org/index.php/icr/article/view/532

Kettani, H. (2010). Muslim population in Asia: 1950-2020. International Journal of Environmental Science and Development, 1(2), 143-153. http://ijesd.org/ papers/28-D437.pdf.

Kettani, H. (2014). The world Muslim population: History \& prospect. Singapore: Research Publishing.

Lickorish, L. J., \& Carson, L. J. (1997). An introduction to tourism. London: Butterworth-Heinemann.

Lindsey, T. (2012). Monopolising Islam: The Indonesian Ulama Council (IUC) and state regulation of the Islamic economy. Journal Bulletin of Indonesian Economic Studies, 48(2), 253-274. https://doi.org/10.1080/ 00074918.2012 .694157$.

Ma'mur, J. (2018). The role of the MUI fatwa in the nation and state: Talfiq Manhaji as a methodology for determining the MUI fatwa. Wahana Akademika, 5(2), 41-52. https://doi.org/10.21580/wa.v5i2.3226

Mansouri, S. (2014). Role of halal tourism ideology in destination competitiveness: A study on selected hotels in Bangkok, Thailand. Proceedings International Conference on Law, Education and Humanities (ICLEH'14), Pattaya, Thailand, 30-31-January (pp. 20-23). http://icehm. org/upload/9944ED0114528.pdf

Mohsin, A., Ramli, N., \& Alkhulayfi, B. A. (2016). Halal tourism: Emerging opportunities. Tourism Management Perspectives, 19, 137-143. https://doi.org/10.1016/j. tmp.2015.12.010

Muhamad, N., Sulaiman, S., Akmaliah, K. A., \& Said, M. F. (2017). Halal tourism: Literature synthesis and direction for future research. E-Proceeding International Halal Management Conference (IHMC), Sejong University, Korea Selatan, 17-18 Agustus (pp. 1-13). http://psasir.upm.edu.my/id/ eprint/75416/ 
Mulyati, M. (2019). MUI's contribution to the development and application of Islamic law in Indonesia. Al-Mashlahah: Jurnal Hukum dan Pranata Sosial Islam, 7(1), 83-100. http://dx.doi.org/10.30868/am.v7i01.547

Namin A. A, T. (2012). Islam and tourism: A review on Iran and Malaysia. International Research Journal of Applied and Basic Sciences, 3, 2809-2814.

Pamukcu, H., \& \& Arpaci, O. (2016). A new trend in the Turkish tourism industry: Halal tourism. In: C.Avcikurt, M.S.Dinu, N.Hacioglu, R.Efe, A.Soykan \& N.Tetik (Eds.), Global issues and trends in tourism. Turki: ST. Kliment Ohridski University Presssofia.

Pew Research Center - Forum on Religion \& Public Life (PRC-FRPL). (2011). The future global Muslim population projections for 20102030. Washington, DC: Pew Research Center.

Pradesyah, R. \& Khairunnisa, A. (2018). Analysis of the application of the MUI fatwa on halal tourism: A case study of the Medan Syariah hotel. Intiqad: Jurnal Agama dan Pendidikan Islam, 10(2), 334-348. https:// doi.org/10.30596/intiqad.v10i2.1986

Priyadi, U. P. (2016). Islamic tourism prospects and developments. Yogyakarta, Indonesia: UPP STIM YKPN.

Saleh, R., \& Anisha, N. (2019). Halal tourism in Aceh: Ideas and realities on the ground. Sahafa Journal of islamic Comunication, 1(2), 81-92. http://dx.doi.org/10.21111/ sjic.v1i2.2849

Sanad, H. S., Kassem, A. M., \& Scott. (2010). Bridging tourism theory and practice. In: J. Scott \& J. Jafari (Eds.), Tourism and Islamic law (pp. 17-30). Amerika Serikat: Emerald Group Publishing Limited. https://doi.org/10.1108/S20421443(2010)0000002030
Setiyanto, D. A. (2018). Fatwa as social engineering media: Analysis of MUI fatwa in post-reform family law. Al-Ahkam, 3(1), 85-106. https://ejournal.iainsurakarta. ac.id/index.php/alahkam/article/view/1342 Suharko, S., Khoiriati, S. D., Krinajaya, I. M., \& Dinarto, D. (2018). Institutional conformance of halal certification organisation in halal tourism industry: The cases of Indonesia and Thailand. Tourism Review, 66(3), 334-348. https://hrcak. srce.hr/206165

Tawil, N. M., Ramlee, S., Jaafar, J., \& Saat, F. M. (2015). An overview of foodpreneur awareness among small and medium-sized enterprises (SME) of halal certification. Asian Social Science, 11(21), 91-94. https://doi.org/10.5539/ass.v11n21p91

Theobald, W. F. (2005). Global tourism (3rd ed.). Amerika Serikat: Elsevier-Science.

Wahyudi, H. F., \& Fajar, F. (2018). The Ijtihad method of the fatwa commission of the Indonesian Ulema Council and its application in the fatwa. Cakrawala: Jurnal Studi Islam, 13(2), 120-133. https://doi. org/10.31603/cakrawala.v13i2.2402

Yusoff, S. Z., \& Adzharuddin, N. A (2017). Factor of awareness in searching and sharing of halal food product among Muslim families in Malaysia. Proceedings. SHS Web of Conferences 33 i-COME'16, Kuala Lumpur, 18-20 Malaysia. https://doi.org/10.1051/ shsconf/20173300075

Vulcan Post. (2019). The Muslim travel market is growing, but where are its unicorns? https://vulcanpost.com/654890/muslimtravel-market-unicorn/ 